\title{
Studi Awal Analisis Molekuler Human Papillomavirus dari Apusan Glans dan Batang Penis
}

\author{
Maya Savira ${ }^{1}$, Resty Yuwandari ${ }^{2}$, Yossi Maryanti ${ }^{3}$, Rahmat Azhari Kemal ${ }^{4}$, Donel. $\mathrm{S}^{5}$
}

\begin{abstract}
Abstrak
Pria juga dapat mengalami keganasan akibat infeksi Human Papillomavirus (HPV) serta bertindak sebagai reservoir virus. Metode skrining HPV pada wanita telah terstandardisasi, namun belum ada standar metode skrining pada pria di Indonesia. Beberapa studi pada populasi pria di luar negeri menunjukkan potensi sampling pada daerah genitalia eksterna untuk skrining HPV. Tujuan: mengoptimasi metode skrining HPV secara molekuler pada pria. Metode: Responden adalah partner seksual wanita pansien kanker serviks di RSUD Arifin Achmad Provinsi Riau. Apusan dari glans dan batang penis diambil menggunakan nylon-flocked swab yang kemudian dimasukkan ke dalam $350 \mu \mathrm{l}$ viral transport medium terpisah. DNA diisolasi dari sampel yang kemudian dianalisis untuk mendeteksi gen human $\beta$-globin dan HPV. Hasil: Optimasi awal menunjukkan gen $\beta$-globin dapat terdeteksi dari hasil ekstraksi dengan kit Zeesan Viral RNA Extraction. Pita HPV hasil PCR dengan primer MY09 dan MY11 dapat muncul namun masih tipis. Simpulan: Studi awal ini menunjukkan bahwa apusan glans dan batang penis dapat digunakan untuk deteksi HPV secara molekuler pada pria, namun proses pengambilan sampel, ekstraksi DNA, dan PCR masih perlu dioptimasi.
\end{abstract}

Kata kunci: apusan, glans, HPV, penis

\begin{abstract}
Men can also develop infection-associated malignancies as well as act as a viral reservoir. The screening method for HPV is women have been standardized, but there has not been a standardized screening method for men in Indonesia. Several studies abroad have shown the potential of external genital sampling for HPV screening. Objectives: To optimized the HPV molecular screening method for men in Indonesia. Methods: Respondents were sexual partners of cervical cancer patients in Arifin Achmad General Hospital, Riau Province. Samples from glans and penile shafts were taken using a nylon-flocked swab, which was subsequently put into separate tubes containing $350 \mu l$ of viral transport medium. DNA was isolated from samples and analyzed to detect the human $\beta$-globin gene and HPV. Results: The initial optimization showed that the $\beta$-globin gene was detected using DNA extracted by Zeesan Viral RNA Extraction kit. PCR using MY09 and MY11 primers showed the target HPV band; however, the bands were still faint. Conclusion: This preliminary study showed that glans' and penile shaft swabs could be used for HPV molecular detection in men, however the sampling methods, DNA extraction methods, and PCR still need further optimization.
\end{abstract}

Keywords: glans, Human papillomavirus, penis, swab

Affiliasi penulis: ${ }^{1}$ KJFD Mikrobiologi, Fakultas Kedokteran Universitas Riau, Pekanbaru, Indonesia. ${ }^{2}$ Fakultas Kedokteran Universitas Riau, Pekanbaru, Indonesia. ${ }^{3}$ KJFD/KSMNeurologi, Fakultas Kedokteran Universitas Riau / RSUD Arifin Achmad Provinsi Riau, Indonesia. ${ }^{4}$ KJFD Biologi Kedokteran, Fakultas Kedokteran Universitas Riau, Pekanbaru, Indonesia. ${ }^{5} \mathrm{KJFD} / \mathrm{KSM}$ ObstetriGinekologi, Fakultas Kedokteran Universitas Riau, Pekanbaru, Indonesia.

Korespondensi:rahmat.azharikemal@lecturer.unri.ac.id

\section{PENDAHULUAN}

Human papillomavirus (HPV) adalah virus dari famili Papillomaviriade, yang merupakan virus DNA untai ganda, non-envelop dan berukuran relatif kecil sekitar 8000 bp dengan diameter 45-55 mm. ${ }^{1}$ Diketahui terdapat lebih dari 100 jenis HPV dan 80 genom berhasil ditemukan, 40 diantaranya ditularkan melalui hubungan seksual. Berdasarkan tempat 
predileksi infeksinya, diketahui bahwa virus ini sebagian besar ditularkan akibat adanya kontak skinto-skin, terutama hubungan seksual termasuk seks oral, seks anal, dan hand sex. HPV dapat juga ditularkan melalui transmisi vertikal ibu - bayi dan penggunaan alat yang terkontaminasi. ${ }^{2}$ HPV dapat menginfeksi sel pada permukaan kulit di genital, anus, mulut, dan kerongkongan, tetapi tidak melalui darah ataupun organ internal seperti jantung atau paru-paru. Tropisme HPV adalah pada sel epitel kulit dan mukosa. $^{3}$

Ada banyak studi mengenai hubungan infeksi HPV dengan kejadi kanker serviks. Pria juga dapat mengalami keganasan akibat infeksi HPV sekaligus berperan sebagai reservoir virus. Estimasi prevalensi HPV pada pria adalah sebesar $20 \%$, berkisar dari $2 \%$ hingga $35 \%$. ${ }^{4}$ Prevalensi HPV lebih tinggi pada pria yang merupakan pasangan wanita dengan cervical intraepithelial neoplasia, yaitu sebesar $49.1 \%$, berkisar antara $12.9 \%$ hingga $86 \%{ }^{5}$ Studi pada pasangan Iran yang dirujuk untuk pemeriksaan HPV, 16.3\% pasangan memiliki kesamaan HPV positif. ${ }^{6}$ Studi pada 50 orang pria pasangan seksual wanita dengan infeksi HPV genital, $76 \%$ ditemukan positif DNA $\mathrm{HPV}^{7}$ Dengan demikian, diperlukan metode untuk skrining HPV pada pria, terutama pada pasangan wanita dengan infeksi HPV.

Metode skrining HPV untuk wanita telah terstandardisasi, namun belum ada metode standar untuk pria. ${ }^{3}$ Beberapa literatur telah membandingkan beberapa daerah untuk pengambilan sampel pada pria di luar negeri. ${ }^{8-11}$ Situs anatomi eksternal seperti glans dan batang penis dapat memberikan sampel yang adekuat dan tingkat deteksi HPV yang tinggi. Oleh karena itu, penelitian melakukan studi awal analisis molekuler HPV pada apusan glans dan batang penis pada pria pasangan pasien kanker serviks.

\section{METODE}

Responden adalah dua orang pria yang merupakan pasangan seksual dari wanita kanker serviks di RSUD Arifin Achmad Provinsi Riau. Kriteria pasangan wanita adalah: (1) Dirujuk sebagai suspek kanker serviks pada KSM Obstetri-Ginekologi, RSUD Arifin Achmad; (2) Dilakukan biopsi serviks dengan metode punch biopsy; dan (3) Memiliki pasangan pria tetap, yaitu telah menikah dan aktif secara seksual minimal selama 6 bulan.

Metode pengambilan sampel apusan / swab penis mengadaptasi Giuliano (2007). ${ }^{8}$ Responden diminta untuk tidak berhubungan seksual selama 24 jam sebelum kunjungan pengambilan sampel. Apusan swab diambil terpisah untuk seluruh permukaan (1) glans penis/coronal sulcus dan (2) batang penis (termasuk permukaan dalam dan luar prepusium, jika ada). Swab dimasukkan ke dalam $350 \mu$ viral transport medium (VTM). Spesimen lalu divorteks sebelum diekstraksi. ${ }^{12,13}$

Optimasi dilakukan dengan membandingkan kit ekstraksi. Sebanyak $250 \mu \mathrm{l}$ viral transport medium(VTM) ditambahkan ke dalam mikrotub yang telah berisi swab dan VTM. Sebanyak $250 \mu$ sampel digunakan untuk ekstraksi asam nukleat dengan kit Zeesan Viral RNA Extracation, dan 300 $\mu$ l sampel digunakan untuk ekstraksi asam nukleat dengan kit Wizard Genomic DNA Purification.

Analisis PCR gen human $\beta$-globin dilakukan dengan pasangan primer $\mathrm{GH} 20$ dan PC04. Komposisi PCR mix adalah 1X GoTaq 2X Green Master Mix, 0.5 $\mu \mathrm{M}$ masing-masing primer. Untuk optimasi, variasi volume DNA template yang digunakan adalah $2 \mu \mathrm{l}$ dan $4 \mu \mathrm{l}$. Kondisi PCR dilakukan dengan initial denaturation $95^{\circ} \mathrm{C} 2$ menit, 30 siklus amplifikasi (denaturasi $95^{\circ} \mathrm{C}$ 30 detik, annealing $55^{\circ} \mathrm{C} 1$ menit, dan elongasi $72^{\circ} \mathrm{C} 1$ menit), dan elongasi akhir $72^{\circ} \mathrm{C} 8$ menit. Hasil PCR dielektroforesis pada agarose $2 \%, 75 \mathrm{~V}, 40$ menit. Sampel yang terdeteksi gen $\beta$-globin lalu digunakan untuk deteksi HPV dengan menggunakan primer konsensus universal (MY09 dan MY11) dengan komposisi dan kondisi PCR yang sama dengan PCR B-globin. $^{14-17}$

\section{HASIL}

Pada dua individu yang digunakan dalam studi awal ini diambil sampel dari glans dan batang penis. individu Pertama diisolasi Zeesan Viral RNA Extraction. Elektroforesis hasil PCR $\beta$-globin dari kedua situs sampling (Gambar 1) menunjukkan adanya pita target berukuran sekitar 200-300 bp. Secara umum, pita hasil PCR dengan volume template $2 \mu \mathrm{l}$ memunculkan pita yang lebih tebal 
dibandingkan volume template $4 \mu \mathrm{l}$. Dengan demikian, komposisi DNA yang digunakan adalah $2 \mu$ l.

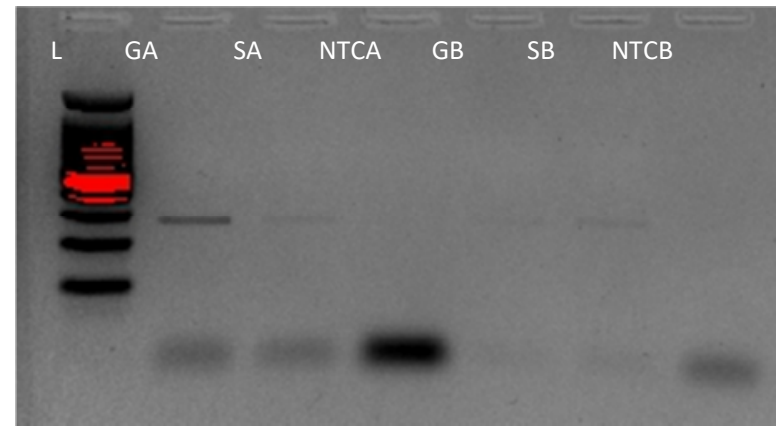

Gambar 1. Hasil elektroforesis sampel situs glans $(G)$ dan batang (S) dengan volume template (A) $2 \mu \mathrm{l}$ dan (B) $4 \mu \mathrm{l}$. L: DNA Ladder 100bp. NTC: kontrol negatif.

Optimasi selanjutnya adalah melalui perbandingan kit ekstraksi. Hasil ekstraksi menunjukkan bahwa hasil ekstraksi menggunakan kit Zeesan memunculkan pita yang lebih tebal dibandingkan kit Wizard (Gambar 2). Namun, pita yang muncul berukuran 700-800 bp, tidak sesuai ukuran target $\beta$-globin. Hal ini berbeda dengan proses optimasi sebelumnya, yang dapat dikarenakan sampel yang digunakan untuk optimasi ekstraksi (Individu 2) berbeda dengan sampel yang digunakan untuk optimasi volume DNA template (Individu 1). Oleh karena itu, dilakukan perbandingan hasil PCR $\beta$-globin antara sampel individu 1 dan individu 2 yang diekstraksi dengan kit Zeesan. Hasil Gambar 3 menunjukkan bahwa pola pita yang dihasilkan cukup konsisten dengan hasil PCR sebelumnya. Sampel glans (G1) menghasilkan pita target dengan jelas, sampel batang (S1) tidak menghasilkan pita target dengan jelas, sedangkan sampel ketiga (G3 dan S3) menghasilkan pita nonspesifik dengan ukuran 700-800 bp. Oleh karena itu, disimpulkan bahwa perbedaan pola pita dapat disebabkan oleh perbedaan kualitas sampel.

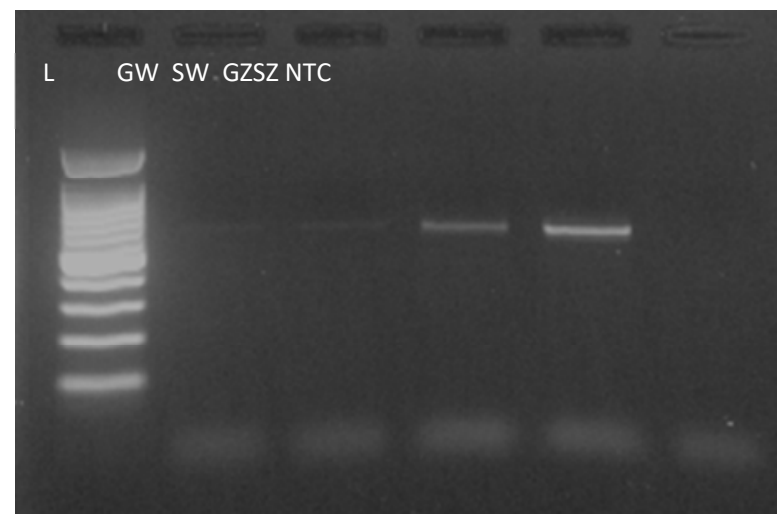

Gambar 2. Hasil elektroforesis sampel situs glans (G) dan batang (S) yang diekstraksi dengan kit (W) Wizard dan (Z) Zeesan. L: DNA Ladder 100bp. NTC: kontrol negatif.

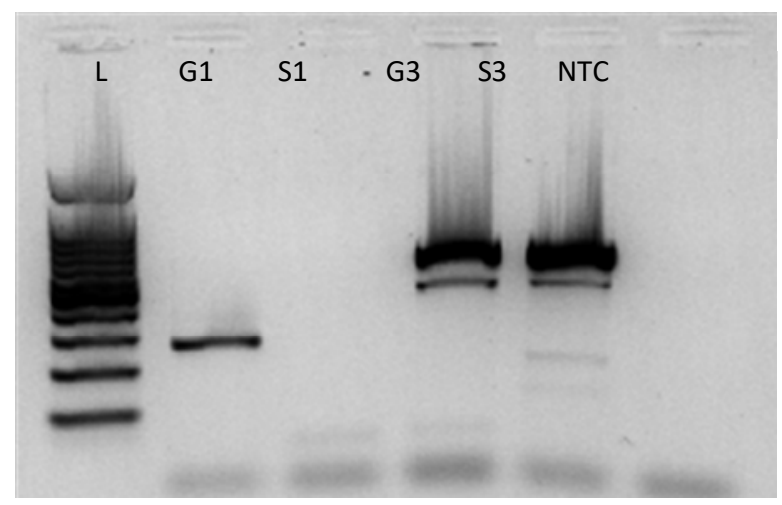

Gambar 3. Hasil elektroforesis $\beta$-globin sampel individu 1 dan 2 pada situs glans ( $\mathrm{G} 1$ dan $\mathrm{G} 2$ ) dan batang (S1 dan S2). L: DNA Ladder 100bp. NTC: kontrol negatif.

Keempat template DNA memunculkan pita setelah PCR dengan primer $\beta$-globin, maka keempat sampel digunakan untuk deteksi HPV dengan primer MY09 \& MY11. Hasil Gambar 4 menunjukkan bahwa dari kedua situs sampel 3 terdapat pita target HPV berukuran 400-500 bp. Namun, pita primer dimer masih cukup tebal, sehingga komposisi PCR masih perlu dioptimasi. Selain itu, pita target masih cukup tipis, yang dapat dikarenakan konsentrasi DNA target yang rendah. 


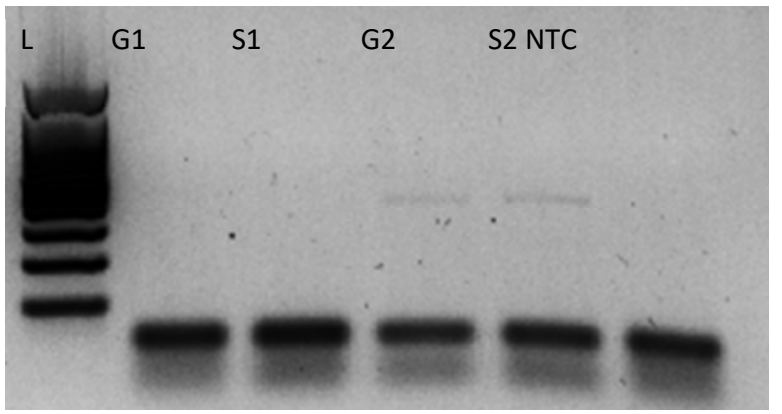

Gambar 4. Hasil elektroforesis HPVsampel individu 1 dan 2 pada situs glans ( $\mathrm{G} 1$ dan $\mathrm{G} 2$ ) dan batang (S1 dan S2). L: DNA Ladder 100bp. NTC: kontrol negatif.

\section{PEMBAHASAN}

Elektroforesis hasil PCR $\beta$-globin dari kedua situs sampling (Gambar 1) menunjukkan adanya pita berukuran sekitar 200-300 bp. Ukuran tersebut sesuai dengan prediksi panjang target, yaitu $268 \mathrm{bp} .{ }^{18}$ Volume templateterkait dengan konsentrasi DNA. Peningkatan volume template dapat meningkatkan konsentrasi DNA di dalam reaksi, namun juga berpotensi meningkatkan jumlah inhibitor di dalam reaksi. Hal-hal tersebut dapat menyebabkan hasil PCR yang lebih baik dengan menggunakan volume template $2 \mu$ l.

Hasil ekstraksi menunjukkan bahwa hasil ekstraksi menggunakan kit Zeesan memunculkan pita yang lebih tebal dibandingkan kit Wizard (Gambar 2). Hal ini dapat dikarenakan efisiensi penangkapan asam nukleat pada kit Zeesan yang berbasis magnetik dapat menghasilkan yield yang lebih baik. Kit Zeesan ditujukan untuk ekstraksi RNA virus, sementara kit Wizard ditujukan untuk ekstraksi DNA genom. Walaupun demikian, beberapa metode ekstraksi asam nukleat berbasis magnetik dapat mengekstraksi DNA dan RNA secara simultan. ${ }^{19,20}$ Dengan demikian, penggunaan kit Zeesan diperkirakan masih tetap dapat mengisolasi DNA manusia yang ditandai oleh teramplifikasinya gen $\beta$-globin.

Keempat sampel (dua pasang suami-isteri) yang digunakan dapat memunculkan pita hasil pada PCR gen $\beta$-globin, sehingga dapat digunakan untuk deteksi HPV molekuler.menunjukkan bahwa dari kedua situs sampel 3 terdapat pita target HPV berukuran 400-500 bp, sesuai dengan ukuran target 450 bp menurut Wanderlei-Silva (2005) Hasil PCR menghasilkan pita primer dimer masih cukup tebal, sehingga komposisi PCR, terutama komposisi primer, masih perlu dioptimasi. Selain itu, pita target masih cukup tipis, yang dapat dikarenakan konsentrasi DNA target yang rendah. Salah satu upaya optimasi yang dapat dilakukan adalah menggunakan kit ekstraksi DNA berbasis kolom atau magnetik sehingga lebih sesuai dengan HPV sebagai virus DNA.

Sampel batang penis individu pertama (S1) tidak memunculkan pita $\beta$-globin yang tegas, sehingga tidak munculnya pita HPV dapat dikarenakan sampel yang tidak adekuat. Sementara itu, sampel DNA dari glans individu pertama (G1) memunculkan pita $\beta$ globin yang tegas namun tidak memunculkan pita HPV. Hal ini dapat disimpulkan sebagai tidak terdeteksinya HPV pada sampel tersebut. Walapun demikian, sampel tersebut dapat diuji dengan primer konsensus lainnya, seperti GP5+/GP6+. Walaupun kedua pasangan primer memiliki kemampuan yang hampir identic dalam deteksi HPV, perbedaan subtipe HPV dapat mempengaruhi efisiensi deteksi. Oleh karena itu, disarankan untuk menggunakan lebih dari satu pasangan primer untuk meningkatkan sensitivitas deteksi HPV dari sampel klinis. ${ }^{21}$

\section{SIMPULAN}

Gen $\beta$-globin dapat terdeteksi dari hasil ekstraksi apusan (swab) glans dan batang penis. Primer MY09/MY11 dapat menghasilkan pita target HPV pada sampel glans dan batang penis pada salah satu responden pria pasangan wanita kanker serviks, walaupun pita masih cukup tipis dengan primer dimer yang tebal. Hal ini sesuai dengan penelitian yang dilakukan di luar negeri yang menemukan HPV pada glans dan prepusium pria pasangan wanita yang terdeteksi positif DNA HPV. ${ }^{6}$

\section{SARAN}

Diperlukan optimasi lebih lanjut mengenai pengambilan sampel, ekstraksi DNA, dan PCR untuk deteksi HPV pada pasien pria. Penggunaan pasangan primer HPV lain, seperti GP5+/GP6+, perlu dilakukan untuk meningkatkan sensitivitas deteksi HPV. ${ }^{14-17}$

\section{UCAPAN TERIMA KASIH}

Terima kasih atas hibah penelitian dosen pemula Fakultas Kedokteran UNRI 2020. 


\section{DAFTAR PUSTAKA}

1. de Villiers EM, Fauquet C, Broker TR, Bernard $\mathrm{HU}$, zur Hausen $\mathrm{H}$. Classification of Papillomaviruses. Virology. 2004;324:17-27.

2. Schellekens MC, Dijkman A, Aziz MF, Siregar B, Comain S, Uljee SK, et al. Prevalence of single and multiple HPV types in cervical carcinomas in Jakarta, Indonesia. Gynecol Oncol. 2004;93(1):49-53.

3. Lieblong B, Montgomery BEE, Joseph Su L, Nakagawa M. Natural history of human papillomavirus and vaccinations in men: $A$ literature review. Health Sci Rep. 2019;2(5):e118.

4. Garutti P, Montori S, Bazzan E, Tarabbia C. Gender differences in the epidemiology and prevention of human papillomavirus (HPV) and HPV-related diseases. Ital J Gender-Specific Med. 2018;4(4):152-61.

5. Skoulakis A, Fountas S, Peteinelli MM, Pantelidi $\mathrm{K}$, Petinaki E. Prevalence of human papilloma virus and subtype distribution in male partners of women with cervical intraepithelial neoplasia (CIN): a systematic review. BMC Infect Dis. 2019;19(2):192.

6. Davarmanesh M, Dezfulian M, Gharavi MJ, Younesi S, Saadati P, Amin MMT, et al. Human papilloma virus (HPV) genotypes concordance between Iranian couples referrals. Infect Agent Cancer. 2019;14:22.

7. Nicolau SM, Camargo CGC, Stávale JN, Castelo A, Dores GB, Lorincz A, et al. Human papillomavirus DNA detection in male sexual partners of women with genital human papillomavirus infection. Urology. 2005;65(2):251-5.

8. Giuliano AR, Nielson CM, Flores R, Dunne EF Abrahamsen M, Papenfuss MR, et al. The optimal anatomic sites for sampling heterosexual men for human papillomavirus (HPV) detection: The HPV detection in Men Study. J Infect Dis. 2007;196(8):1146-52.

9. Smith JS, Moses S, Hudgens M, Agot K, Franceschi S, Maclean I, et al. Human papillomavirus detection by penile site in young men from Kenya. Sex Transm Dis. 2007;34(11):928-34.
10. Koene F, Wolffs P, Brink A, Dukers-Muijrers N, Quint W, Bruggeman $C$, et al. Comparison of urine samples and penile swabs for detection of human papillomavirus in HIV-negative Dutch men. Sex Transm Infect. 2016;92(6):467-9.

11. Profozic Z, Mestrovic T, Savic I, Profozic V. Prevalence of HPV infection in Croatian men during a 12-year period: a comparative study of external genital and urethral swabs. Cent Eur J Public Health. 2016;24(4):321-5.

12. Brownlow RJ, Dagnall KE, Ames CE. A Comparison of DNA Collection and Retrieval from Two Swab Types (Cotton and Nylon Flocked Swab) when Processed Using Three QIAGEN Extraction Methods. J Forensic Sci. 2012;57(3):713-7.

13. Bruijns BB, Tiggelaar RM, Gardeniers $H$. The Extraction and Recovery Efficiency of Pure DNA for Different Types of Swabs. J Forensic Sci. 2018;63(5):1492-9.

14. Safanah A, Djuminar A, Merdekawati $F$, Kurniawan E, Ernawati E. Optimasi volume templat dna dan jumlah siklus amplifikasi untuk deteksi Wuchereria bancrofti metode real-time PCR. J Ris Kesehat Poltekkes Depkes Bandung. 2019;11(2):160.

15. Yuenleni. Langkah-Langkah Optimasi PCR. Indones J Lab. 2019;1(3):51-6.

16. Aqzayunarsih, Andriani I, Agus R, Marwayana O. Optimasi PCR: Konsentrasi Primer dan Volume Templat DNA Pada Amplifikasi mtDNA Ikan Medaka Oryzias spp. di Daerah Aliran Sungai (DAS) Maros (disertasi). Makassar: Fakultas Matematika dan IImu Pengetahuan Alam. Universitas Hasanuddin; 2015.

17. Pharmawati M. Optimalisasi Ekstraksi Dna Dan Pcr-Rapd Pada Grevillea Spp. (Proteaceae). J Biol. 2014;13(1):12-6.

18. Wanderlei-Silva D, Al. E. High quality DNA from Human Papillomavirus (HPV) for PCR/RFLPs. Braz Arch Biol Technol. 2005;48(1):27-40.

19. Wang J, Ali Z, Wang N, Wenbiao L, Liu H, Li F, et al. Simultaneous extraction of DNA and RNA from Escherichia coli BL 21 based on silicacoated magnetic nanoparticles. Sci China Chem. 2015;58:1774-8. 
20. He H, Li R, Chen Y, Pan P, Tong W, Dong X, et al. Integrated DNA and RNA extraction using magnetic beads from viral pathogens causing acute respiratory infections. Sci Rep. $2017 ; 7: 45199$
21. Venceslau EM, Bezzera MM, Lopes ACM, Souza EV, Onofre ASC, de Melo CM, et al. HPV detection using primers MY09/MY11 and GP5+/GP6+ in patients with cytologic and/or colposcopic changes. J Bras Patol Med Lab. 2014;50(4):280-5. 